\title{
Transition in chemical and mineralogical composition around unweathered relicts of granodiorite in the kaolin deposit on Bornholm, Denmark
}

\author{
JAN BONDAM \& MANFRED STÖRR
}

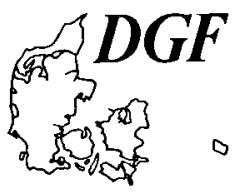

\begin{abstract}
Bondam, J. \& Störr, M.: Transition in chemical and mineralogical composition around unweathered relicts of granodiorite in the kaolin deposit on Bornholm, Denmark. Bull. geol. Soc. Denmark, Vol. 37, pp. 117-122, Copenhagen, October 14th, 1988.

In the kaolin deposit near Rønne on the island of Bornholm in the Baltic Sea a number of well-rounded, unweathered, boulder-like relicts of the granodioritic parent rock are found, embedded in kaolin.

Samples have been taken of one relict at $2 \mathrm{~cm}$ interval from the fresh material outwards into the kaolin. The distribution pattern of the major elements in these samples has been studied in order to gain an impression of the leaching conditions at the time of formation, in the immediate vicinity of the relict. This distribution shows on a minor scale, what previously has been demonstrated in bulk for the whole deposit that leaching effects have not been uniform for the different elements, leading to a relative enrichment of calcium in the transition zone close to the unweathered parent rock. TEM and SEM observations revealed that halloysite and smectite are the dominant clay minerals of the transition zone, where kaolinite occurs only sporadically. These minerals apparently become unstable when alkalis and alkali earths are progressively leached, while kaolinite emerges as the pincipal clay mineral, and amphibole and plagioclase no longer remain in the residual mineral assemblage.
\end{abstract}

Jan Bondam, The Geological Survey of Greenland, Øster Voldgade 10, DK-1350 Copenhagen, Denmark; Manfred Störr, Ernst-Moritz-Arndt Universität, Sektion Geologische Wissenschaften, Jahnstrasse 17a, DDR-2200 Greifswald, DDR, June 15th, 1988.

\section{Introduction}

The in situ weathered kaolin deposit near Rønne, in the western part of the island of Bornholm in the Baltic Sea, contains a number of wellrounded relicts of unweathered granodioritic bedrock of Precambrian age.

A geological sketch-map of the deposit and its immediate surrounding is reproduced in fig. 1. Fig. 2 shows the relict, embedded in kaolin, on which this study is based. The locality is called Rosvang, situated in the northeastern part of the elongated deposit at an elevation of $31 \mathrm{~m}$, which is $7 \mathrm{~m}$ above the underlying, unweathered granodiorite.

A description of the kaolin deposit has earlier been given by Almeborg, Bondam \& Heller (1969). The geochemistry of the deposit was studied by Bondam $(1967,1969)$.

The present study deals with the distribution of the major elements and the mineralogical composition of rock samples, taken at $2 \mathrm{~cm}$ interval, from the fresh parent rock of the relict to $10 \mathrm{~cm}$ outward from it, into the surrounding kaolin. Additionally, a sample of kaolin was taken at a distance of $20 \mathrm{~cm}$ from the fresh rock. A short description of the samples is included in figure. 3 .

The samples were chemically analysed at the laboratories of the ceramic works of A/S Hasle Klinker- og Chamottestensfabrik in Rønne.

Electron microscope images of the sample material and X-ray diffraction patterns of the clay minerals were obtained at the Sektion Geologische Wissenschaften, Ernst-Moritz-Arndt University, Greifswald.

\section{Decomposition and neoformation of mineral content}

The transformation of the granodiorite to kaolin in a transition zone only a few centimetres thick is apparent from the distribution of the mineral components. In this zone amphibole, plagioclase 


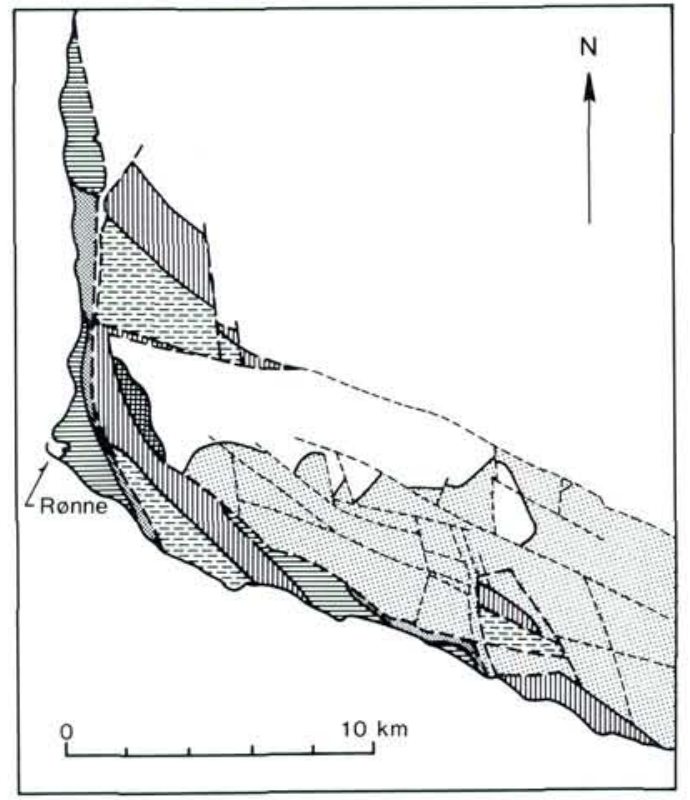

LEGEND

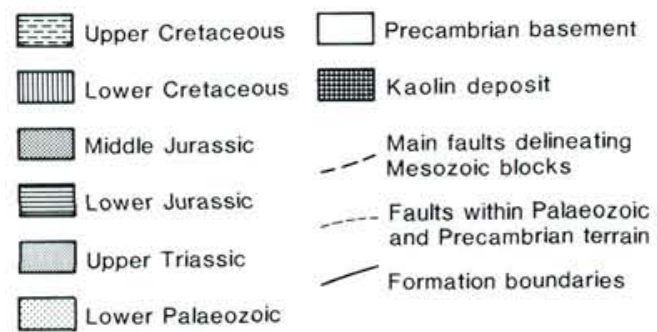

Fig. 1 Geological sketchmap of the area around Rønne, Bornholm. Modified and simplified from Graversen et al. (1982).

and biotite are decomposed, while quartz and microcline are retained (fig. 3).

The newly reconstituted clay minerals were smectite, halloysite and kaolinite. In the two samples with dark-coloured biotite, at 2 and $4 \mathrm{~cm}$ respectively, from fresh rock, the amphibole and plagioclase are already largely replaced by clay minerals. Smectite was identified by X-ray diffraction. Apparently its formation was enhanced by the early release of $\mathrm{Mg}^{++}$from the amphibole. Simultaneously biotite was degraded to hydrobiotite, as revealed by the expanded d(001)-spacing, approximating $11.0 \AA$. The replacement of plagioclase was initiated by the formation of tubular halloysite, while kaolinite occurs only as a few, isolated flakes (fig. 4). The amount of halloysite gradually reaches its peak value of about
40 per cent of the clay mineral components at a distance of $6 \mathrm{~cm}$ from fresh parent rock (figs. 5 and 6).

At a distance of $8 \mathrm{~cm}$ the amount of halloysite already is so much reduced that only single tubes can be observed. Fine-grained, pseudohexagonal kaolinite (fig. 7) has become the dominant stable alteration product. In white, soft kaolin, at 10 and $20 \mathrm{~cm}$ distances, only kaolinite and scattered particles of the unstable clay minerals, smectite and halloysite, are observed. Single quartz grains do not show conclusive signs of dissolution at the grain surface. This may be due to the very irregular grain shape, which hampers the observation of true corrosion marks.

\section{Distribution of the major elements in whole rock analyses}

The decomposition of the primary minerals in granodiorite and the neoformation of clay minerals is accompanied by changes in chemical composition, due to gradual leaching of major elements during the process of kaolinization.

Figure 8 shows the relative distribution of $\mathrm{Na}_{2} \mathrm{O}, \mathrm{K}_{2} \mathrm{O}, \mathrm{MgO}, \mathrm{CaO}$ and $\mathrm{SiO}_{2}$, as compared to the content of $\mathrm{Al}_{2} \mathrm{O}_{3}$ in dry weight of the samples. The numbers are given as ratios of each

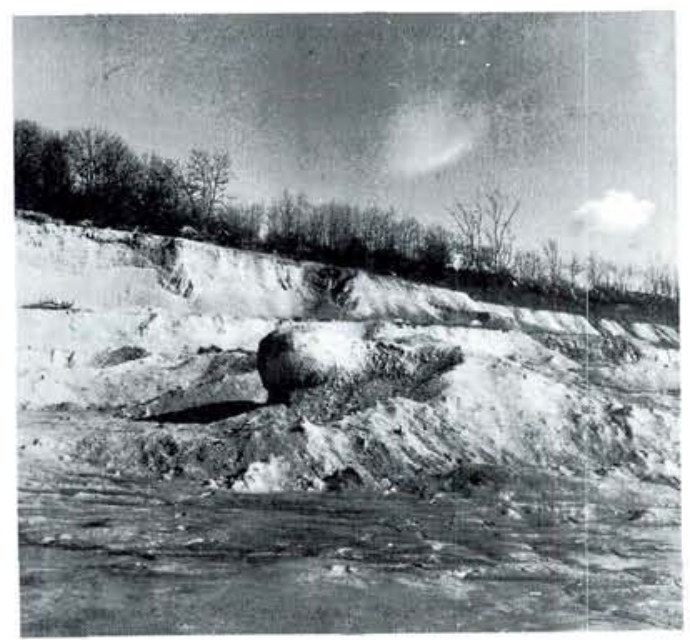

Fig. 2 Unweathered relict of granodiorite, embedded in kaolin, Rosvang. 


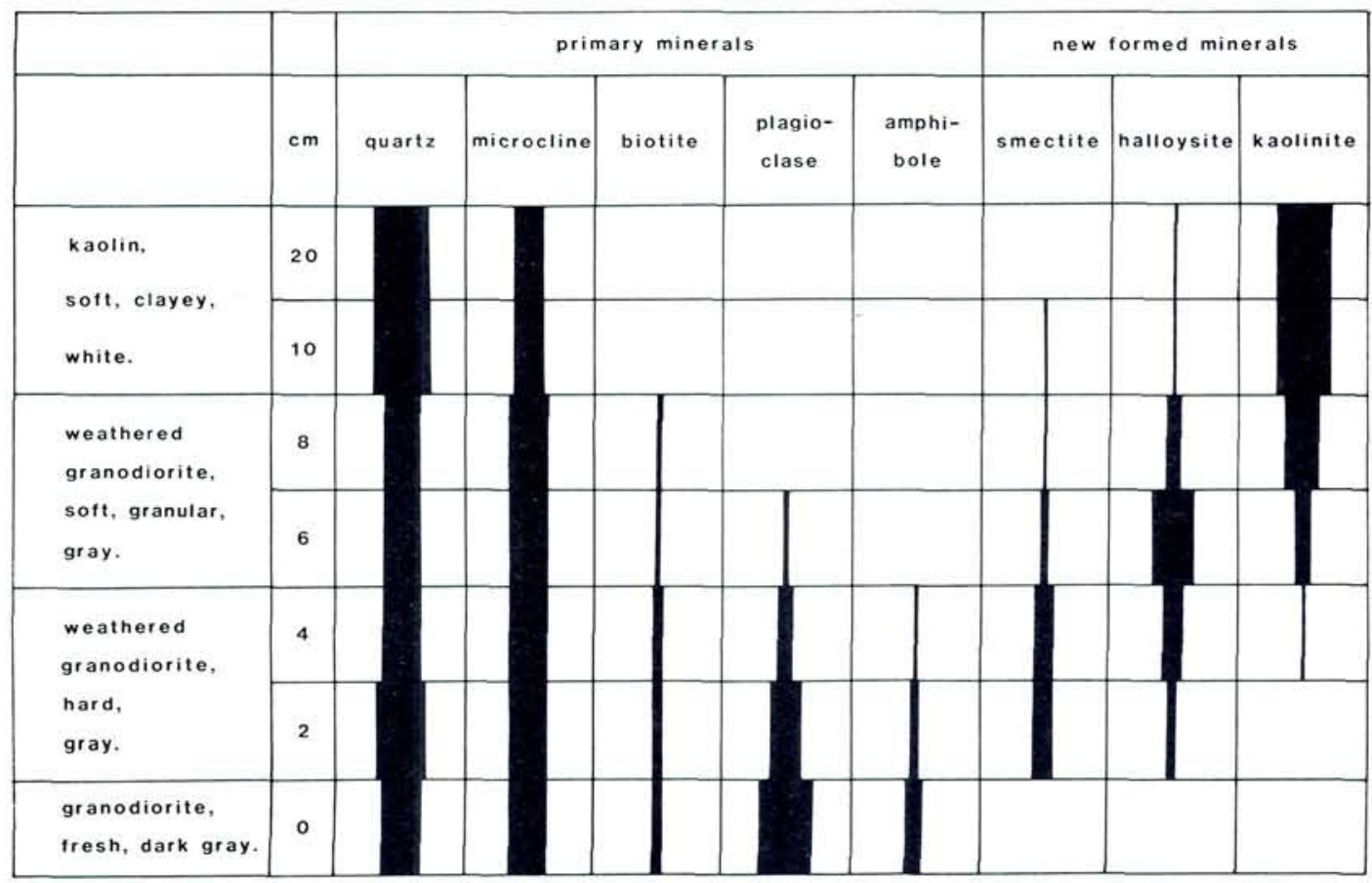

Fig. 3 Schematic distribution of mineral components in the transition zone from granodiorite to kaolin. For comparative reasons the modal composition of the granodiorite is given as: $21 \%$ quartz, $22 \%$ microcline, $37 \%$ plagioclase, $10 \%$ amphibole, $5 \%$ biotite, and $5 \%$ other minerals.

of the above mentioned major elements against alumina, on the assumption that during kaolin weathering the alumina component is retained in the residuals, while the other major elements are leached.

The distribution pattern is zoned, and shows a number of features relevant to the nature of transformation of the parent rock. The zone im-

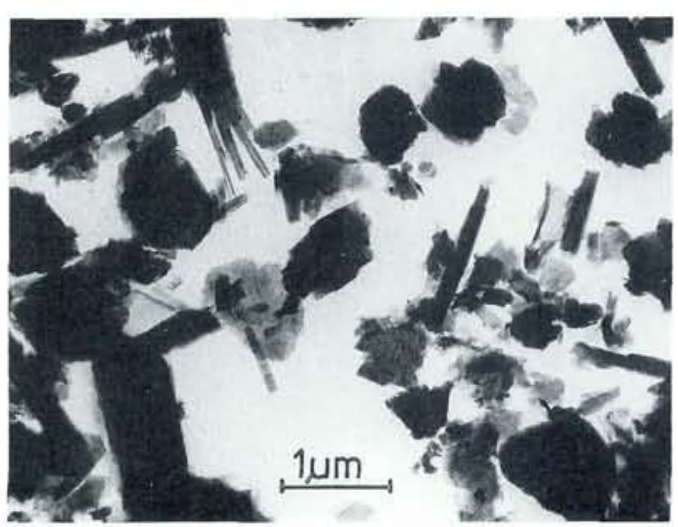

Fig. 4 Smectite and halloysite alongside primary minerals $(2$ $\mathrm{cm})$. TEM mediately adjacent to the unweathered granodiorite is already strongly depleted with respect to $\mathrm{Na}_{2} \mathrm{O}, \mathrm{K}_{2} \mathrm{O}$ and $\mathrm{MgO}$. However, $\mathrm{CaO}$ is enriched while $\mathrm{SiO}_{2}$ is depleted symmetrically to the augmented $\mathrm{Al}_{2} \mathrm{O}_{3}$ content of the sample.

The trend of the $\mathrm{Fe}_{2} \mathrm{O}_{3}$ distribution closely resembles that of $\mathrm{MgO}$. It has been omitted from fig. 8 for reasons of clarity but included in fig. 9 .

At around $4 \mathrm{~cm}$ from fresh rock the trend is reversed, and depletion of $\mathrm{CaO}$ has been initiated.

At $10 \mathrm{~cm}$ distance, sodium, calcium, magnesium and iron seem to have been leached to a stage of equilibrium. Significant further leaching

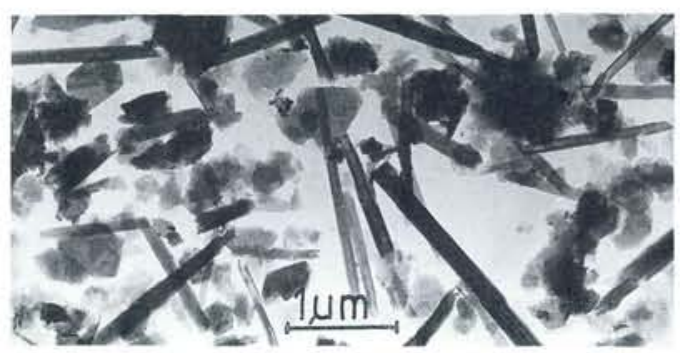

Fig. 5 Abundant smectite and halloysite with single flakes of kaolinite in clayey substance at $4 \mathrm{~cm}$ distance. TEM. 


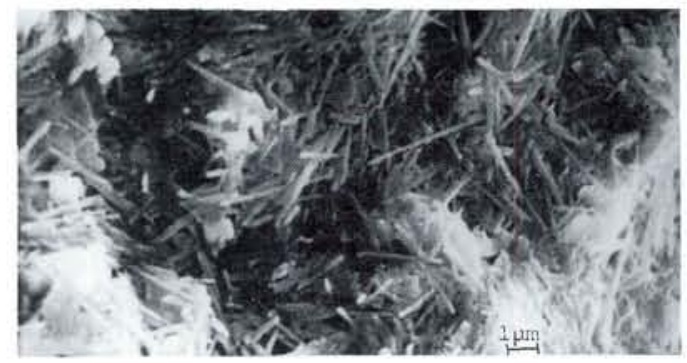

Fig. 6 Predominant halloysite at $6 \mathrm{~cm}$ distance. TEM.

affects silica and potassium, as indicated by the distribution ratio at a distance of $20 \mathrm{~cm}$ from the fresh rock.

Fig. 9 highlights the distribuion pattern of selected major elements in order to accentuate the difference between the distribution of sodium and potassium, and the similarity between the distribution of sodium and potassium, and the similarity between the alumina content of the residuals and the $\mathrm{H}_{2} \mathrm{O} / \mathrm{Al}_{2} \mathrm{O}_{3}$ ratio.

In addition the distribution of $\mathrm{Fe}_{2} \mathrm{O}_{3}$ has been included. It shows that iron is leached as readily as sodium.

A logarithmic scale has been used for the ratio numbers, and distributions of 4 samples only, from 4 to $10 \mathrm{~cm}$ distance from fresh parent rock, have been illustrated.

\section{Discussion}

From the above observations on the pattern of major element distribution in the immediate vicinity of the unweathered relict, it can tentatively be concluded that the stability relations of the main mineral constituents of the parent rock, along with reconstituted residual mineral assemblages, are not simple.

Compared with the evidence obtained from the electron microscope images, it may be argued that the decomposition of the primary minerals along with the neoformation of residual clay minerals proceeds stepwise, and is related to different weathering environments.

Although it is evident that neither pyroxenes, amphiboles, feldspars nor mica, as main mineral constituents, are stable under the prevailing conditions, the retention of $\mathrm{CaO}$ close to the parent rock is not in accordance with the generally ac- knowledged instability of plagioclase in a weathering environment as shown by the concurrent rapid decrease of sodium in the rock sample.

It has previously been demonstrated that, in bulk, two distinct weathering parageneses are found in the kaolin deposit on Bornholm (Bondam, 1967). These parageneses have respectively been called I-paragenesis for the residual sequence in which an appreciable amount of mica is found as a stable clay mineral component together with some smectite, while some calcite occurs in kaolin with an alumina content of less than 22 per cent dry weight, and the $K$-paragenesis for a sequence void of calcite, and with a low mica content. Szpila (1972) has shown that a like development is found in depth in the Wyszonowice deposit in Poland.

Reichelt and Neuzil (1978) observed a similar, depth related distribution pattern for the major elements in the kaolin-weathered, sericite-rich phyllites of south Moravia in Czechoslovakia.

The distribution pattern of the major elements around the unweathered relict does in fact, on a small scale, mirror two distinct weathering environments. In the zone from zero to $4 \mathrm{~cm}$ stagnant leaching conditions lead to clay mineral assemblages of I-paragenetic affinity, while the distribution pattern from about $6 \mathrm{~cm}$ outwards is similar to a K-paragenetical development of residual kaolin weathering.

The initial formation and rapid decomposition of halloysite in the transition zone from fresh parent rock to kaolin is noteworthy. This devel-

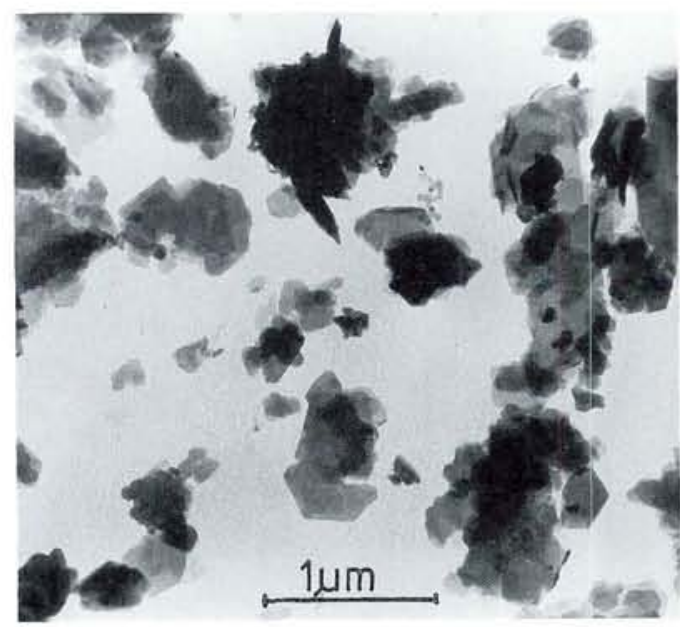

Fig. 7 Kaolinite flakes at $8 \mathrm{~cm}$ distance. TEM. 


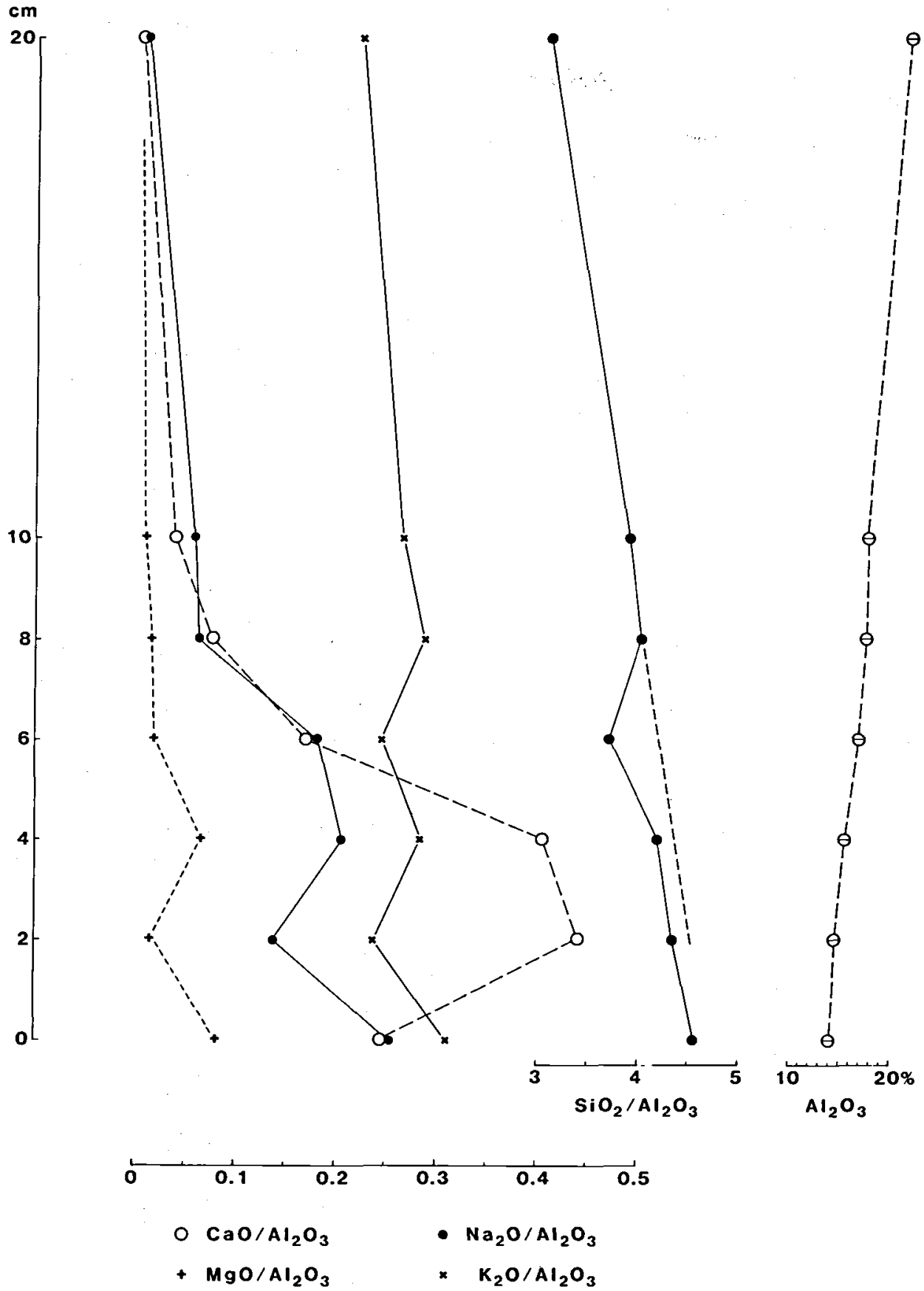

Fig. 8 Distribution ratios of a number of major elements, as compared to the alumina content, at spacings of $2 \mathrm{~cm}$ from the parent rock. 

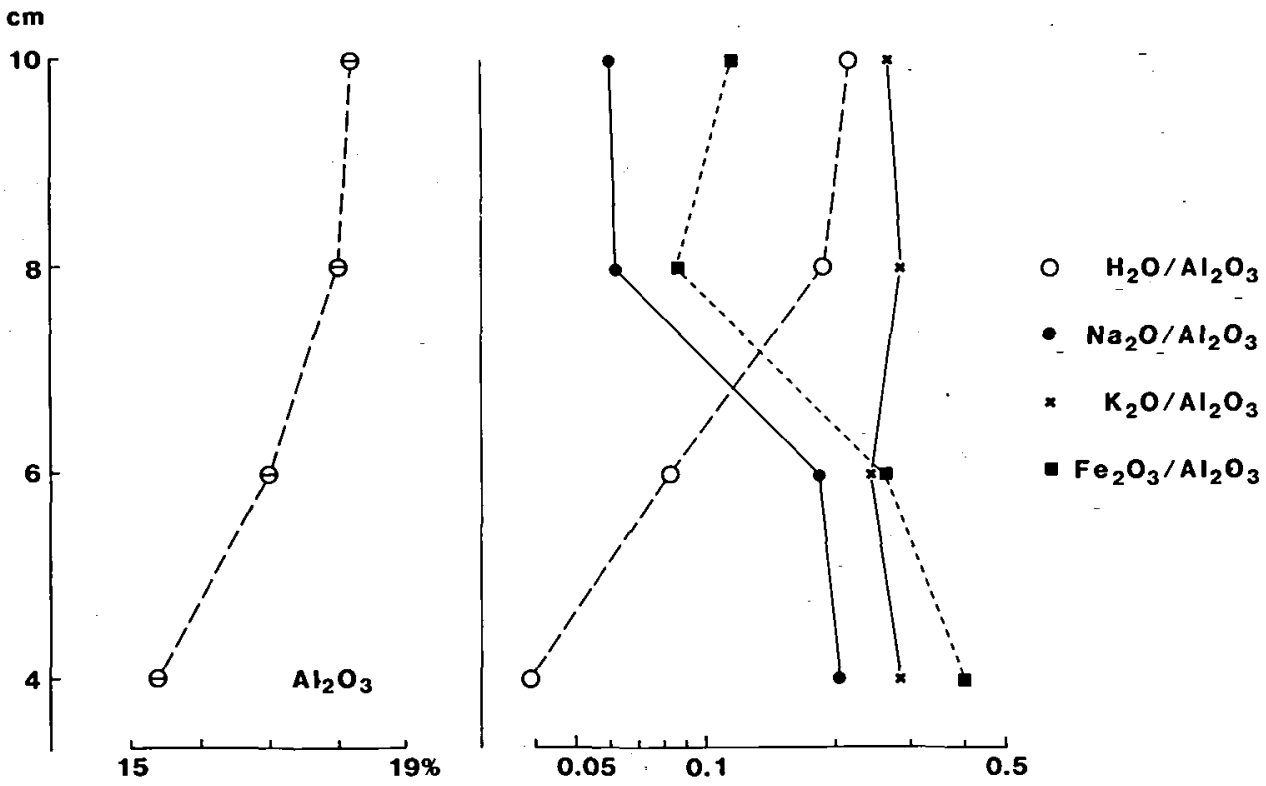

Fig. 9 Distribution ratios of $\mathrm{H}_{2} \mathrm{O}, \mathrm{Na}_{2} \mathrm{O}, \mathrm{K}_{2} \mathrm{O}$ and $\mathrm{Fe}_{2} \mathrm{O}_{3}$ between 4 and $10 \mathrm{~cm}$ distance from unweathered parent rock.

opment proceeds parallel with the decrease of alkalis and alkali earths in the samples, and shows that, under those conditions, halloysite is as stable as smectite. A very similar occurrence of halloysite was described by W. D. Keller (1977) in the transition zone from granite to kaolin near Sparta, Georgia, USA. The transition zone at this locality is only a few centimetres thick and contains abundant halloysite, which in part forms regular "whisker crusts".

\section{References}

Almeborg, J., Bondam, J. \& Heller, E., 1969: Kaolin Deposits of Denmark. Proc. XXIII Int. Geol. Congr. 15, 75-84.
Bondam, J., 1967: Undersøgelser vedrørende de geokemiske forhold i kaolinforekomsten ved Rønne på Bornholm (English summary). Bull. geol. Soc. Denmark 17, 297-356.

Bondam, J., 1969: Investigations in the Geochemical Distribution of the Major Elements in some Kaolin Deposits. Proc. XXIII Int. Geol. Congr. 14, 63-78.

Graversen, P., Rolle, F. \& Surlyk, F., 1982: Lithostratigraphy and sedimentary evolution of the Triassic, Jurassic and Lower Cretaceous of Bornholm, Denmark. Geol. Survey Denmark, Series B, no. 7.

Keller, W. D., 1977: Scan electron micrographs of kaolins collected from diverse environments of origin. IV Georgia Kaolin and kaolinizing source rocks. Clay and Clay Minerals. 25, 311-345.

Reichelt, M. \& Neuzil, J., 1978: Zur Kaolinisierung der feldspatfreien Gesteine der Inneren Phyllite der Böhmischen Massiv (Südmähren). Schriftreihe f. Geol. Wiss. Heft 11, 233-242. V. Internationales Symposium - Genese des Kaolins, Akademi-Verlag, Berlin.

Szpila, K., 1972: Chemical variability of original kaolins in Wyszonowice deposit, Poland. Int. Clay Conf., Kaolin Symp., Madrid, pp. 111-123. 